„Studia Wyborcze”, tom 30, 2020

DOI: https://doi.org/10.26485/SW/2020/30/7

Maryanne Awiti Ochieng;*

\title{
PETITIONS TO THE SUPREME COURT QUESTIONING THE RESULTS OF PRESIDENTIAL ELECTIONS IN KENYA A BRIEF HISTORY AND A FOCUS ON THE SUPREME COURT'S DECISION OF 2017
}

\section{INTRODUCTION}

This article begins with a brief historical overview to help the reader understand the status and evolution of Kenya's political and electoral system. The overview also sets a foundation for the reader to understand the quest for electoral justice and the events leading up to the electoral reforms.

Kenya was under a multiparty system upon independence in 1963 with the late President Jomo Kenyatta elected as the first president of the Republic of Kenya [Kanyinga 2014: 8-9]. He was then re-elected under a de facto one party system both in 1969 and 1974. Upon his demise in 1978, he was succeeded by the late President Moi who was elected unopposed still under a de facto one party system [Kanyinga 2014]. He was then re-elected unopposed under the de jure single party state effected by a constitutional amendment. ${ }^{1}$ This meant that only one political party had the right to form and run the government based on the existing Constitution and that all other political parties at the time were banned [Monyani 2018].

\footnotetext{
* LLB Graduate and Advocate Trainee at the Kenya School of Law, Nairobi, Kenya, ochiengmaryanne@gmail.com

${ }^{1}$ Independence Constitution, Section 2(a).
} 
The clamour for multi-party democracy in the 1990s resulted in a constitutional amendment declaring the Republic of Kenya a multi-party democratic state. ${ }^{2}$ Consequently, the 1992 presidential elections and subsequent elections have been held under this regime [Kanyinga 2014: 8-9]. The opposition was defeated by President Moi in the 1992 presidential elections, and a total of six petitions were filed challenging his victory, all of which were dismissed on procedural or technical grounds. The petition filed by Kenneth Matiba, a presidential candidate in the 1992 polls, was dismissed on the grounds that he had not personally signed the petition. He had been detained by President Moi's regime for political reasons in the 1990s, as a result of which he suffered physical incapacitation and, as such, granted his wife power of attorney [Kamau 2017].

In December 2007, Kenyans went to the polls for the fourth time under the multi-party regime [Majanja 2016: 2-3]. This presidential election in particular was highly competitive and contested. The announcement of the presidential election results saw an outbreak of violence in several parts of the country that lasted for almost two months [Brownsell 2013]. The violence left more than 1,000 people dead with over 300,000 people displaced [Rawlence 2008]. It took the intervention of the international community to end the violence. The late Kofi Annan led the mediation talks between the two leading protagonists, Mwai Kibaki and Raila Odinga. The end result of the mediation talks was the signing of the Kenya National Accord and Reconciliation Agreement between the two principals, Mwai Kibaki and Raila Odinga [Obonyo 2008]. As a result of the agreement, there was a constitutional amendment creating a Prime Minister position and ultimately a coalition government between Mwai Kibaki as the President and Raila Odinga as the Prime Minister.

To get to the root cause of the election debacle and pave the way for reforms, the Independent Review Commission (IREC), also known as the Kriegler Commission, was appointed. ${ }^{3}$ The commission's mandate was to examine the 2007 elections from different angles, inter alia the constitutional and legal framework, with a view to identifying the weaknesses and inconsistencies, and the composition and structure of the then electoral management body, in order to assess its independence and capacity, vote counting and tallying to assess integrity and to make recommendations for electoral reforms. ${ }^{4}$

As a result of the above, the then electoral management body, the Electoral Commission of Kenya (ECK) was disbanded and replaced by an Interim Independent Electoral Commission (IIEC) and Interim Boundaries Commission

\footnotetext{
${ }^{2}$ Repealed Constitution, Section 1A.

${ }^{3}$ The Commission was appointed under the Commission of Inquiry Act, Cap 102 and its formation formally gazetted through Gazette Notice No. 1983 of 2008.

${ }^{4}$ Report of the Independent Review Commission on the General Elections held in Kenya on $27^{\text {th }}$ December 2007, Nairobi 2008, p. 3.
} 
(IBC) mandated to spearhead electoral reforms. The reforms included inter-alia the creation of a new voters' register, the introduction of electoral technology and proposals on boundary limitations [Majanja 2016: 4-5]. The reform processes further culminated in the promulgation of a new Constitution on $27^{\text {th }}$ August, 2010.

The Constitution of Kenya, 2010 states that all sovereign power belongs to the people of Kenya, ${ }^{5}$ which is exercised either directly or through democratically elected representatives. ${ }^{6}$ To complement the Constitution, the Elections Act, 2011, and other relevant statutes were enacted to provide a reformed administrative and legal environment for the conduct of elections. Some of the notable reforms introduced by the new Constitution regarded principles governing elections. It was stated that elections are to be free and fair, ${ }^{7}$ free from violence and intimidation ${ }^{8}$ and administered in an impartial, neutral, efficient, accurate and accountable manner. ${ }^{9}$

Some of the weaknesses of the electoral management body identified by the Kriegler Commission report included: irregularities in voter register which excluded $30 \%$ of potential voters; the relayed results facing integrity questions; a defective system of vote tallying and relaying of information, a composition of the electoral body that raised suspicion among the opposition; and the incompetence of the electoral management body's officials with the chairman having stated that it was impossible to establish who won the elections. ${ }^{10}$ As such, the new Constitution addressed the weaknesses of the electoral management body as identified by the Kriegler Commission report. ${ }^{11}$ The Independent Electoral and Boundaries Commission (IEBC) was thereby established, ${ }^{12}$ and it derives its mandate solely from the Constitution. The independence of the Commission in the management and conduct of elections, which is critical to the legitimacy of any election is also provided for. The Constitution also established the Supreme Court of Kenya, ${ }^{13}$ which is the apex court and has exclusive and original jurisdiction to hear and determine disputes arising from presidential elections. ${ }^{14}$

\footnotetext{
${ }^{5}$ Article 1(1) Constitution of Kenya, 2010.

${ }^{6}$ Article 1(2) Constitution of Kenya, 2010.

${ }^{7}$ Article 81(e) Constitution of Kenya, 2010.

${ }^{8}$ Article 81(e) (ii) Constitution of Kenya, 2010.

${ }^{9}$ Article 81(e)(v) Constitution of Kenya, 2010.

${ }^{10}$ Report of the Independent..., pp. 21-23.

${ }^{11}$ Transparency International. Kriegler Commission Report: An Audit of Its Implementation, pp. 9-11, https://issuu.com/ti-kenya/docs/krigler_report_commission_report_an_audit_of_its_i (access 12.08.2020).

${ }^{12}$ Article 88(1) Constitution of Kenya, 2010.

${ }^{13}$ Article 163(1) Constitution of Kenya, 2010.

${ }^{14}$ Article 163(3)(a), Constitution of Kenya, 2010.
} 
For the first time under the new Constitution, Kenyans went to the polls on $4^{\text {th }}$ March 2013 [Gatehouse 2013]. On $9^{\text {th }}$ March 2013, IEBC's chairman, Isaac Hassan announced the presidential election results declaring Uhuru Kenyatta as the president elect. Subsequent to the announcement, three petitions challenging the presidential election results were filed at the Supreme Court and by directions of the court, the three petitions were consolidated. ${ }^{15}$ The agreed issues for trial were inter alia whether the president elect and deputy president elect were validly elected, whether the presidential election was conducted in a free, fair and transparent manner in compliance with the provisions of the constitution and relevant provisions of law, and whether rejected votes ought to have been included in determining the final votes. ${ }^{16}$

The court carefully considered the facts of the petitions, the submissions by the parties and the evidence presented, and came to the following conclusion; that the evidence did not disclose any serious irregularities in the management of the electoral process, neither did it impeach the mode of participation by any of the candidates in the electoral process. Lastly, the court found that the candidate declared as president elect had obtained the basic vote threshold, therefore justifying his being declared as such. Accordingly, the court disallowed the 2013 presidential petition and upheld the presidential election results declared by IEBC on $9^{\text {th }}$ March 2013.

In August 2017, Kenyans went to the polls for a second time under the new Constitution and election laws but the presidential election results were contested at the Supreme Court. Consequently, the presidential election was nullified by the apex court by a majority decision of four judges in favour of the petition, with two dissenting. With the above background on presidential elections in Kenya, we shall focus on the nullified presidential elections of $2017 .{ }^{17}$ The opposition's presidential candidate, Raila Amolo Odinga, and his running mate, Stephen Kalonzo Musyoka were the petitioners. The respondents were the Independent Electoral and Boundaries Commission as the electoral management body, its Chairman, Wafula Chebukati and the incumbent at the time, President Uhuru Kenyatta. ${ }^{18}$

15 Raila Odinga \& 5 others versus Independent Electoral and Boundaries Commission $\& 3$ others [2013].

${ }^{16}$ Petition No. 5,3 \& 4 of 2013.

${ }^{17}$ Petition No. 1 of 2017.

${ }^{18}$ Raila Amolo Odinga \& another versus The Independent Electoral \& Boundaries Commission $\& 2$ others. 


\section{BRIEF FACTS}

Kenya held its second general election after the entry into force of the 2010 Constitution on $8^{\text {th }}$ August, 2017. This date is important because it was the first election held under an elaborate regime of electoral laws, specifically amendments to the Elections Act which introduced the Kenya Integrated Electoral Management System (KIEMS). The KIEMS kit was a new device for electronic voting used during the 2017 elections. It included a laptop with a fingerprint reader and a hand held device with an in built finger print reader. It was used in the biometric voter registration and voter identification on Election Day as well as in the simultaneous transmission of presidential election results from the polling stations to the national tallying centre.

The chairman of the electoral management body, IEBC declared the incumbent, President Uhuru Kenyatta, as the winner of the presidential election and the first petitioner, Raila Odinga, as the runner up on $11^{\text {th }}$ August, 2017. As a result, the petitioners moved to court on $18^{\text {th }}$ August, 2017, challenging the announced presidential election results. It was the petitioners' argument that the electoral management body conducted the elections in a manner that failed to comply with the governing principles of elections as established in the Constitution of Kenya, Elections laws and Regulations.

The petitioners' raised a number of issues. ${ }^{19}$ Firstly, it was averred that the IEBC had violated the principles set out in the Constitution, Electoral laws and Regulations and as such had usurped the people's sovereignty as the election was conducted contrary to said principles. Secondly, it was claimed that the IEBC had blatantly flouted the principles of a free and fair election under the Constitution as read together with the Elections Act and Regulations by committing massive systemic and systematic irregularities that greatly undermined the foundation of the Kenyan system as a sovereign republic. Thirdly, it was claimed that there was corruption, misconduct and improper, undue influence especially by President Uhuru Kenyatta who allegedly intimidated and coerced voters and also sponsored publications and advertisements in print and electronic media through the famous Presidential Delivery Unit using tax payers money contrary to the provisions of the Elections Act. Fourthly, it was the petitioners' submission that there was a failure in the process of relaying and transmitting results as the IEBC inordinately delayed the transmission, which was coupled with other factors that exposed KIEMS to unlawful interference and the manipulation of results. Fifthly, the petitioners' claimed that there was substantive non-compliance, irregularities and improprieties that significantly affected results and, as such, that the IEBC could not accurately determine the votes that any of the candidates had received.

${ }^{19}$ Raila Odinga \& another versus the Independent Electoral \& Boundaries Commission $\& 2$ others [2017] eKLR. 
The petitioners further averred that there were errors in voting, counting and tabulation of results as these were not openly and accurately collated and that the IEBC inflated votes in favour of President Uhuru Kenyatta. It was also the petitioners' submission that there was an unprecedented and contradictory quantity of rejected votes that had an effect on the outcome of the election. Finally, it was the petitioners' submission that the use of the term 'OR' in section 83 of the Elections Act unlike the term 'AND' in the English equivalent Act, made the two limbs disjunctive and not conjunctive, the effect of which shall be explained later in this article. As such, they urged the court to depart from its interpretation of the section as was in the 2013 presidential petition.

The petitioners concluded their submissions and made their petitions, inter alia a declaration that the presidential election held on $8^{\text {th }}$ August 2017 was not conducted in accordance with the Constitution and the applicable electoral laws, thus rendering the declared results invalid, null and void and any other orders that the court deemed fit to grant.

The respondents' filed their answers to the petition in which they dismissed the petitioners' allegations entirely. They maintained that they had done everything in full compliance with the law and that the petitioners' allegations were unfounded. Regarding Section 83 of the Elections Act, the Respondents averred that non-compliance with the law alone, without evidence that the electoral process had been fundamentally flawed, cannot be the basis for invalidating an electoral outcome. They also claimed that the petitioners had the legal burden of not only proving that there was non-compliance with the law but also - and this is the crucial point - that the non-compliance affected the results of the election. Lastly, it was their submission that if indeed there were any irregularities as alleged by petitioners, then these were inter alia human, administrative, clerical, computation and erroneous recording which did not in any way affect the results. In sum, it was the respondents' submission that the petition was devoid of any merit and should be dismissed with costs.

\section{EXAMINING THE LEGAL PRINCIPLES}

Before proceeding to determine the matter, the court discussed some of the identifiable legal principles that emerged from the case and which in turn would guide the court in determining the petition as follows: 


\section{BURDEN OF PROOF}

It is trite law that the burden of proof is on the person who alleges a fact to prove it. As such, the court relied on Section $107^{20}$ and judicial precedents as it reiterated the position in the 2013 Presidential petition. ${ }^{21}$ It stated that a petitioner who seeks the nullification of an election on the grounds of non-conformity with the law, or on the basis of irregularities, must therefore adduce credible and cogent evidence to prove the grounds raised to the satisfaction of the court.

As such, it was the court's assertion that it was common ground that the petitioners bore the legal burden of proving to the required standards that on account of non-conformity with the law, and or on the basis of irregularities which in turn affected the election results, the $3^{\text {rd }}$ respondent's election as president should be nullified. It further stated that while the petitioner bears the burden to adduce factual evidence to prove allegations of breach, if not controverted, the burden then shifts to the electoral body to adduce evidence to prove compliance with the law.

\section{STANDARD OF PROOF}

It was the court's position that electoral disputes are normally referred to as sui generis because they are not ordinary civil proceedings. As such, the standard of proof remains higher than on the balance of probabilities but lower than beyond reasonable doubt. The allegations made must therefore be ascertained based on the evidence on record that they were more probable than not to have occurred. Kenyan law being rooted in the common law tradition does not distinguish between public and private law. Therefore, as a matter of principle, electoral petitions are processed according to the Code of Civil Procedure.

\section{VALID VERSUS REJECTED VOTES IN A PRESIDENTIAL ELECTION IN KENYA}

Rejected votes are votes inserted into presidential ballot boxes but which are later rejected for non-compliance with the law on the basis of fraud, duplicity of marking or related short falls. In this regard, the petitioners had urged the court to take into account the rejected votes in ascertaining if a candidate had met the constitutional threshold of $50+1 \%$. The respondents, on the other hand, had submitted that rejected votes were excluded from valid votes in accordance

\footnotetext{
${ }^{20}$ Evidence Act, Cap 80 Laws of Kenya.

${ }^{21}$ Raila Odinga \& 5 others versus Independent Electoral \& Boundaries Commission $\& 3$ others [2013].
} 
with the law and in line with the court's finding during the 2013 Presidential petition. The respondents argued that for predictability and certainty in the application of the law, the petitioners' plea should be dismissed.

The court's finding from comparative jurisprudence from inter alia New Zealand, Canada and South Africa was that rejected votes count for nothing. Consequently, the court took a position that a purposive interpretation of Article $138(4)^{22}$ led to one logical conclusion and that the phrase 'votes cast' in the article meant valid votes.

From the above, and in maintaining the court's view in the 2013 Presidential petition, it was the court's assertion that a rejected vote, which was void and accords no advantage to any candidate could not be used in the computation of determining the threshold of $50+1 .{ }^{23}$ The petitioners' invitation to reverse this was therefore rejected.

\section{The Meaning of Section 83 of the Elections Act}

\section{The Court's Position in 2013 Presidential Petition}

The court in the 2013 Presidential Petition took the approach that was taken by the Supreme Court of Nigeria in interpreting the statutory version of Section 83 in which it stated that:

The burden is on the petitioners to prove that non-compliance has not only taken place but also has substantially affected the results [...] there must be clear evidence of non-compliance, then, that the non-compliance has substantially affected the results.

This meant that the petitioners not only had the burden of proving that there was non-compliance with the law, but also that the non-compliance substantially affected the results in order to successfully void the election.

\section{The Legal Consequence of the Limbs being Disjunctive or Conjunctive}

As stated above, the petitioners submitted that the use of 'OR' and not 'AND' in Section 83 of the Elections Act made the two limbs disjunctive and not conjunctive.

Section 83 of the Elections Act states that:

No election shall be declared to be void by reason of non-compliance with any written law relating to that election if it appears that the election was conducted in

${ }^{22}$ Constitution of Kenya, 2010

${ }^{23}$ Article 138(4)(a) of the Constitution states that a candidate shall be declared elected as president if the candidate receives more than half of the votes cast in the election hence $50+1$. 
accordance with the principles laid down in the Constitution and in that written law OR that the non-compliance did not affect the result of the election.

From the foregoing provision, it was the petitioners' submission that the approach taken by the court during the 2013 Presidential petition meant that a petitioner would have to prove both limbs of the provision by first proving that the election was not conducted in accordance with the principles of election laws and secondly that the non-compliance affected the results of the elections. Further, it was their submission that the narrow and conjunctive interpretation of Section 83 by the court in 2013 undermines the supremacy of the Constitution and suggests that an act can remain valid despite its transgressions of the Constitution so long as it does not affect the results. The respondents, on the other hand, submitted that non-compliance with the law alone without evidence that the results had been materially and fundamentally flawed was not a basis for invalidating election results. As such, the respondents urged the court not to depart from its conjunctive interpretation of section 83 of the Elections Act.

The court therefore stated that in its view, Section 83 was the fulcrum of the petition. It went further to state that the court had failed to give an authoritative interpretation of Section 83 in the 2013 Presidential petition and that, as such, there was a need for it to pronounce this itself on the same verdict. This is because the petition had again been brought before the court for determination.

It was the court's position that the words of section 83 must be given their natural meaning as the wording of the section is clear and unambiguous. Further, it claimed that, the Kenyan system being constitutional, the interpretation of its statutes must also be carried out in a manner that promotes the purpose, values and principles of the Constitution. ${ }^{24}$

The court was thus guided by well-established canons of statute interpretation as well as by the values and principles of the constitution. Also, given the use of the word 'OR' in section 83 of the Election Act, it was of the opinion that the two limbs of the section should be applied disjunctively and not conjunctively. This means that a petitioner who is able to prove either of the two limbs - namely, that the conduct of the election in question substantially violated the principles laid down in the constitution and other written laws on election - will on that ground alone void an election. Also, a petitioner will be able to void an election if he is able to prove that although the election was conducted substantially in accordance with the constitution and election laws, it was fraught with illegalities or irregularities which affected the election results. As such, the court disagreed with the respondents' request not to depart from the court's 2013 conjunctive interpretation position. Ultimately, it was the court's position that a petitioner who could satisfactorily prove either of the two limbs of the

\footnotetext{
${ }^{24}$ Article 259, Constitution of Kenya, 2010.
} 
section could void an election, as the correct interpretation of the section is the one that ensures that elections are a true reflection of the will of the people of Kenya.

\section{ANALYSIS OF ISSUES FOR DETERMINATION}

The court narrowed down to four issues as follows. The first issue was whether the 2017 Presidential election was conducted in accordance with the principles laid down in the Constitution and written law relating to elections. The second issue was whether there were irregularities committed in the conduct of the presidential elections. The third question related to the impact, if any, of any irregularities and illegalities on the integrity of elections. Lastly, the question of what consequential orders, declarations and reliefs the court could grant was considered. Whether the 2017 Presidential Election was conducted in Accordance with the Laid down Constitutional Principles and Written Laws Relating to Elections?

On this issue, it was the petitioners' position that the electoral body, IEBC flagrantly flouted the Constitution and the written laws thus subverting the will of the electorate as the whole process of counting, tallying and transmission of presidential election results lacked fairness and transparency. At this point, since the electoral body had the custody of the record of elections, the burden of proof thus shifted to the electoral body to prove that it had fully complied with the law especially in the transmission of the presidential election results, a burden it had failed to discharge, in the court's view.

At this point, the court recalled the 2007 presidential election results which had been highly contested. As mentioned earlier, the Kriegler Commission was appointed to look into this and its focus was on the integrity of vote counting, tallying and the announcement of presidential election results in $2007 .{ }^{25}$ The commission made significant recommendations including the use of technology in the electoral process. Pursuant to the recommendations, the process of integrating technology in to the conduct of elections gradually began in 2010 with the biometric registration of voters and later the establishment of the Kenya Integrated Electoral Management System (KIEMS) in 2017.

With regard to the deployment of technology in voter registration, identification and transmission of results, Parliament enacted Section $44,{ }^{26}$ which states that:

\footnotetext{
${ }^{25}$ Report of the Independent Review Commission..., pp. 1-3.

${ }^{26}$ Elections Act, No. 24 of 2011.
} 
$[\ldots]$ there is established an integrated electronic electoral system that enables biometric voter registration, electronic voter identification and electronic transmission of results.

Subsection 3 further provides that:

[...] the Commission shall ensure that the technology in use under subsection (1) is simple, accurate, verifiable, secure, accountable and transparent.

The court went ahead and asserted that the legislative enactments have only one objective which is to ensure conformity with the Constitution, that elections are free, fair, transparent and credible. Further, that the terms simple, accurate, verifiable, secure, accountable and transparent grafted in to these provisions are the same constitutional principles in Articles 10, 38, 81 and 86 of the Constitution of Kenya, 2010.

In addition, section 39(1C) of the Elections Act addresses the results transmission aspect, stating that:

For purposes of a presidential election, the Commission shall-

(a) Electronically transmit, in the prescribed form, the tabulated results of an election for the President from a polling station to the constituency tallying centre and to the national tallying centre;

(b) Tally and verify the results received at the national tallying centre; and

(c) Publish the polling result forms on an online public portal maintained by the Commission.

Based on the above constitutional and statutory provisions, the court went ahead to determine whether the 2017 Presidential elections had been held in conformity with the law.

It was the court's finding that the electoral body IEBC and its Chairman, the $1^{\text {st }}$ and $2^{\text {nd }}$ respondents. Failed to offer any reasonable response to the question of whether all forms bearing results had been electronically transmitted to the national tallying centre as required by section 39(1C) of the Elections Act. Transmission of results from the polling stations required either $3 \mathrm{G}$ or $4 \mathrm{G}$ network which was to be provided by the three major mobile network operators in the country. As such, IEBC conducted a network mapping exercise that established that about 11,155 polling stations within the country were not covered by $3 \mathrm{G}$ or 4G network and returning officers in such stations were required to move to points with network coverage in order to transmit the results. The court established that IEBC attributed the failure to electronically transmit results to technology issues. However, the court was unconvinced and asserted that failure to access $3 \mathrm{G}$ and/or $4 \mathrm{G}$ networks did not equate to a failure of technology and that the electoral body could have made prior arrangements for alternative transmission. The court also stated that IEBC had, in one of its press briefings held prior 
to the elections, assured the country that it had engaged three internet service providers to deal with the network challenges. As such, in the court's view, the failure to transmit the results was a clear violation of the law.

In the circumstances, the electoral body had a golden opportunity to debunk the petitioners' claims when the petitioners made an application to be granted permission to scrutinize the ICT logs and servers. Even though IEBC strenuously opposed the application stating that the application for access to its servers would compromise the security of the data in those servers, the court still granted orders for scrutiny. IEBC failed to comply with the court orders and only gave the petitioners a restricted access at the eleventh hour. IEBC's disobedience left the court with no choice but to accept the petitioners' claims that its IT system had been infiltrated and the data therein compromised, therefore bungling the whole transmission system and leaving them unable to verify the data. The simultaneous electronic transmission of the results from the polling stations to the National Tallying Centre was not only intended to facilitate the verification process but was also meant to protect the whole process from potential electoral fraud by eliminating possible human intervention or interference in the results in the tallying chain.

Another issue that the court established and held IEBC responsible for was the unexplained discrepancies on the number of people who voted for the presidential, gubernatorial and members of parliament, raising questions to the validity of the extra votes in the presidential election. To put this into perspective, elections in Kenya for the different elective positions, among them gubernatorial and parliamentary are all held on the same day as the presidential election. As such, the discrepancies denoted that the transmission of the results was not carried out in a manner consistent with the expectations of section 39(1C) of the Elections Act.

The Constitution places a paramount duty on the electoral body to verify the results before declaring them: ${ }^{27}$ that is to ensure that the results declared are the ones recorded at the polling station and not to vary, change or alter the results. Further, the verification process is elaborately provided for in the Elections Act and the Regulations thereunder. However, it was the court's finding that proceedings did not follow this elaborate and clear constitutional and legislative road map. As such, the failure of IEBC and its Chairman (who is the returning officer for the presidential elections) to verify the results before declaring them went against the expectations of Article 138(3)(c) of the Constitution. Also, the failure to electronically and simultaneously transmit results violated the principles of section 39(1C) of the Elections Act. It was the court's assertion, therefore,

\footnotetext{
${ }^{27}$ Article 138(3)(c), Constitution of Kenya, 2010.
} 
that violations of the Constitution and the law call into serious doubt whether the election can be said to have been the free expression of the will of the people as stated in the Constitution. ${ }^{28}$

The court consequently established that the electoral body failed to exercise its powers and functions in accordance with the Constitution and national legislation; that it failed to conduct the elections in a simple, accurate, verifiable, secure and accountable manner and that the electoral body disobeyed court orders to open its servers and logs for inspection. As such, it was the court's finding, after it had carefully considered all the affidavit evidence and submission by parties, that the petitioners' had satisfactorily discharged the legal burden of proving that the 2017 presidential election was a sham. The court also restated that no evidence had been placed before it by the electoral body to suggest that the whole electoral process was conducted in accordance with the law.

As such, based on the above grounds and on the basis of the interpretation that the court gave section 83 of the Elections Act, the court was left with no choice but to nullify the 2017 presidential elections results.

The dissenting judges' view on this was that the majority decision adopted a narrow and restrictive interpretation of Section 83, and the Elections Act in general, in order to assess a claim that the right to vote had been violated. According to the two judges, electoral petitions ought to be determined in the highest consideration of the right to vote in a free and fair election. In summary, it was their view that the Presidential election was conducted in full compliance with the Constitution and applicable electoral laws and that the petitioners had failed to satisfactorily discharge their legal burden of proof.

\section{THE IMPACT OF IRREGULARITIES ON THE INTEGRITY OF ELECTIONS}

The court began by stating that an election is the surest way through which people express their sovereignty. Further, that the Constitution is founded on the unchangeable principle of the sovereign will of the people which is exercised either directly or indirectly through credible elections of representatives. As such, an election must be a true reflection of the will of the people as decreed in Article 38 of the Constitution. ${ }^{29}$

It is against this background that the court considered the impact of irregularities on the Presidential election results. The petitioners had applied for an order for scrutiny and audit of all the prescribed forms, an order which was

\footnotetext{
${ }^{28}$ Article 38, Constitution of Kenya, 2010.

${ }^{29}$ This Article provides for political rights which include the freedom to make political choices and the right to free, fair and regular elections.
} 
granted by the court. Both the petitioners and respondents took part in the exercise and a report endorsed by all the parties was filed. The court established from the report that one of the most glaring irregularities committed by IEBC was the deployment of prescribed forms that either lacked or had different security features, the irregularities of which go to the heart of electoral integrity. It was the court's view that even though it was in agreement with the respondents' submissions that an election should not be disturbed especially where the quantitative results are negligible, quality was just as important as quantity in a Presidential election. It was the court's view therefore that it was upon the court to determine whether the election was marred by irregularities and whether the irregularities were of such magnitude that they had an effect on the results of the elections that no reasonable tribunal would uphold. It was the court's finding that the irregularities mentioned above were of such a substantial nature that no court of good conscience which properly applied its mind to the evidence could declare that they did not matter or that the will of the people had been expressed.

Based on its findings, the court was unable to validate the Presidential election of $8^{\text {th }}$ August, 2017, the results notwithstanding.

\section{CONCLUSION}

To begin with, it is noteworthy that the losers of elections in Kenya, especially of the Presidential elections have always been told to go to court and file petitions if they were aggrieved by the results. This is largely because the Kenyan judiciary had never ruled in favour of the petitioner in a presidential election prior to 2017.

However, in a confident display of judicial independence resulting in a historic ruling, the Supreme Court of Kenya, for the first time ever in the country and in Africa at large, nullified Presidential election results and ordered repeat elections. While this came as a surprise, it was a move welcomed by many. The court not only demonstrated that the sovereignty of the people which is exercised at the ballot mattered, but also that failure to comply with election laws and principles as provided for in the Constitution and relevant Statutes would void an election. In addition, the court set a precedent for other countries around the world like Malawi that presidential election results can be successfully challenged.

In the instant petition, the court settled the law as regards Section 83 of the Elections Act and also established that the results of an election can be overturned if a petitioner proves that an election was not carried out in accordance with the principles laid down in the Constitution and electoral laws. It was also 
established that illegalities and irregularities of a substantial nature can invalidate an election. Finally, the court, having been satisfied that the petitioners had discharged their legal burden and standard of proof, unlike the respondents who failed to do the same when the burden shifted so as to raise substantial doubts with regard to the petitioners', case reached a decision.

By a majority decision of four judges in support of the petition and two judges dissenting, the court made inter alia a declaration that the August 2017 Presidential election was not conducted in accordance with the law and that the declared results were thus null and void. They found that the irregularities had had a substantial effect on the integrity of the elections and also ordered a repeat of the presidential elections within 60 days as required by the Constitution.

Unsurprisingly, the losing party was not pleased with the court's ruling. Neither President Uhuru Kenyatta nor his supporters were satisfied with the decision. This resulted in a backlash against the judges, with the President calling them 'crooks' and promising to revisit the issue. The Executive arm of the government carried this out by imposing budget cuts on the Judiciary which in turn slowed down their activities and the ripple effect was felt among the citizens [Laing 2017].

Secondly, on the issue of technology, while it was introduced to enable simultaneous transmission of results and as a protection against electoral fraud, it is my belief that genuine political good will is required for this to work. While the establishment of IEBC is embedded in the Constitution, and whilst it has to perform its duties independently and by wholly conforming to the Constitution, we must remember that the recruitment of commissioners is, to some extent, politically influenced as it is always surrounded by political debates. For now, we wait for the next general election in 2022 and hope that IEBC will conduct it in conformity with the law.

\section{REFERENCES}

\section{CASES}

Raila Odinga \& 5 Others versus Independent Electoral \& Boundaries Commission \& 3 others [2013] eKLR.

Raila Odinga $\&$ another versus the Independent Electoral \& Boundaries Commission \& 2 others [2017] eKLR. 


\section{LEGISLATION}

Constitution of Kenya, 2010.

Elections Act, No. 24 of 2011.

Evidence Act, Cap 80.

\section{INTERNET SOURCES}

Brownsell James. 2013. "Kenya: What Went Wrong in 2007," Aljazeera, https://www.aljaz eera.com/indepth/features/2013/03/201333123153703492.html (access 2.08.2020).

Gatehouse Gabriel. 2013. "Kenya Election 2013: Voting Around the Country," BBC News, https://www.bbc.com/news/world-africa-21652947 (access 1.08.2020).

Kamau John. 2017. "The Grim History of Presidential Petitions in Kenya," https://www.na tion.co.ke/kenya/news/politics/the-grim-history-of-presidential-petitions-in-kenya--436750 (access 1.08.2020).

Kanyinga Karuti. 2014. "Kenya: Democracy and Political Participation.” https://www.opensocietyfoundations.org/publications/kenya-democracy-and-political-participation (access 11.08.2020).

Laing Aislinn. 2017. "Kenyatta Lashes out at 'crook' Judges who Nullified Election Win Over Raila Odinga." The Times, https://www.thetimes.co.uk/article/kenyatta-urges-calm-afterjudges-nullify-his-election-victory-k0knbqfc0 (access 12.08.2020).

Majanja David J. 2016. Judiciary's Quest for A Speedy and Just Electoral Dispute Resolution Mechanism: Lessons from Kenya's 2013 Elections. In Balancing the Scales of Electoral Justice; Resolving Disputes from the 2013 Elections in Kenya and the Emerging Jurisprudence. Eds. C. Odote, L. Musumba. International Development Law Organization \& Judiciary Training Institute. http://kenyalaw.org/kl/fileadmin/pdfdownloads/JWCReports/Balancing _ the_Scales_of_Electoral_Justice.pdf.

Monyani Margaret. 2018. "One Party State; Is it Good or Bad for Governance," E-International Relations, https://www.e-ir.info/2018/05/25/one-party-state-is-it-good-or-bad-for-governance (access 25.07.2020).

Obonyo Oscar. 2008. "Kenya's 2008 Mediation Talks Were Annan's Most Intensive Intervention," https://www.nation.co.ke/kenya/news/kenya-s-2008-mediation-talks-were-annan-smost-intensive-intervention-78850 (access 2.08.2020).

Rawlence Ben. 2008. "Ballots to Bullets: Organized Violence and Kenya's Crisis of Governance," https://www.hrw.org/report/2008/03/16/ballots-bullets/organized-political-violenceand-kenyas-crisis-governance (access 25.07.2020).

Report of the Independent Review Commission on the General Elections held in Kenya on $27^{\text {th }}$ December 2007, Nairobi 2008, http://kenyalaw.org/kl/fileadmin/CommissionReports /Report-of-the-Independent-Review-Commission-on-the-General-Elections-held-in-Kenyaon-27th-December-2007.pdf (access 2.08.2020).

Transparency International. Kriegler Commission Report: An Audit of Its Implementation, https://issuu.com/ti-kenya/docs/krigler_report_commission_report_an_audit_of_its_i (access 12.08.2020). 


\section{Summary}

This article focuses on Kenya's political system from independence to date; the conduct of elections under different regimes; and the clamour for multi-party democracy in the 1990s. It then delves briefly into the 2007 general elections, in particular the presidential election that was highly competitive, the contested 2007 presidential election results that left many people dead or displaced. Consequently, it explores the state's efforts for electoral reforms that culminated in the promulgation of the new constitution in 2010.

The article also discusses presidential petitions but with a major focus on the 2017 presidential petition. This is mainly because, in a clear demonstration of judicial independence, the Supreme Court nullified the presidential election results on the basis that the election was not conducted in compliance with the principles set out in the Constitution and election laws, and that the presidential election was marred by irregularities.

Keywords: Kenya, presidential election, Supreme Court, Constitution, election laws.

\section{SKARGI WYBORCZE DO SĄDU NAJWYŻSZEGO W SPRAWIE WYNIKÓW WYBORÓW PREZYDENCKICH W KENII KRÓTKA HISTORIA ZE SZCZEGÓLNYM UWZGLĘDNIENIEM WYROKU SĄDU NAJWYŻSZEGO Z 2017 ROKU (streszczenie)}

W artykule przedstawiono system polityczny Kenii od chwili uzyskania niepodległości, przeprowadzanie wyborów w czasie różnych reżimów politycznych, a także żądanie wprowadzenia w latach 90. demokracji wielopartyjnej. Następnie omówione są powszechne wybory w 2007 roku, a przede wszystkich konkurencyjne wybory prezydenckie, podczas których wiele ludzi zginęło lub zaginęło i których wynik był kwestionowany. Analizie poddane są także wysiłki państwa na rzecz reform, których kulminacją było uchwalenie w 2010 roku konstytucji. $\mathrm{W}$ artykule przedstawiono również skargi wyborcze, $\mathrm{w}$ tym przede wszystkim odnoszące się do wyborów prezydenckich w 2017 roku. Istotny był fakt wyraźnego zademonstrowania przez sądownictwo niezależności. Sąd Najwyższy unieważnił wybory prezydenckie i stwierdził, że zostały one przeprowadzone niezgodnie z zasadami określonymi w Konstytucji i prawie wyborczym, a podczas ich trwania miały miejsce liczne nieprawidłowości.

Słowa kluczowe: skarga wyborcza, prawo wyborcze w Kenii, wybory prezydenckie, unieważnienie wyborów, ogłaszanie wyników wyborów.

\section{ACKNOWLEDGEMENT}

This work would not have been possible without the intellectual contribution and criticism and most importantly the invaluable support of Professor Tomasz Milej. 